(C) 2022, The Authors. Published by Elsevier Inc. and Fass Inc. on behalf of the American Dairy Science Association ${ }^{\circledR}$. This is an open access article under the CC BY license (http://creativecommons.org/licenses/by/4.0/).

\title{
Effect of dry-off management on milking behavior, milk yield, and somatic cell count of dairy cows milked in automated milking systems
}

\author{
A. E. France, ${ }^{1,2} \odot$ S. Dufour, ${ }^{2,3} \odot$ D. F. Kelton, ${ }^{2,4} \oplus$ H. W. Barkema, ${ }^{2,5} \odot$ D. Kurban, ${ }^{2,3} \odot$ and T. J. DeVries ${ }^{1,2 *} \odot$ \\ ${ }^{1}$ Dept. of Animal Biosciences, University of Guelph, ON, N1G 2W1, Canada \\ ${ }^{2}$ Mastitis Network, Saint-Hyacinthe, QC, J2S 2M2, Canada \\ ${ }^{3}$ Department of Pathology and Microbiology, Faculty of Veterinary Medicine, University of Montreal, Saint-Hyacinthe, QC, J2S 2M2, Canada \\ ${ }^{4}$ Department of Population Medicine, University of Guelph, ON, N1G 2W1, Canada \\ ${ }^{5}$ Department of Production Animal Health, Faculty of Veterinary Medicine, University of Calgary, AB, T2N 1NA, Canada
}

\begin{abstract}
Milk production may be reduced before dry-off to decrease the risk of cows developing intramammary infections during the dry period. Such reductions in milk may be possible in automated milking systems (AMS) where milking frequency and feed allocation at the AMS can be controlled at the cow level. This study investigated the effect of dry-off management of cows milked in AMS on milk yield, milking behavior, and somatic cell count (SCC). Using a $2 \times 2$ factorial arrangement of treatments, applied from d 14 to 1 before dry-off, 445 cows from 5 commercial dairy farms in Quebec, Canada, were assigned within farm to either (1) reduced feed [RF; allowed a maximum of $0.75 \mathrm{~kg} / \mathrm{d}$ of AMS pellet for the first week (14 to $8 \mathrm{~d}$ before dryoff) of treatment, and $0.50 \mathrm{~kg} / \mathrm{d}$ for the second week (7 to $1 \mathrm{~d}$ before dry-off) of treatment], or (2) nonreduced feed (NF; allowed up to $2 \mathrm{~kg} / \mathrm{d}$ of AMS pellet), and either (1) reduced milking (RM; reduced to 2 milkings/d or as many times as required to yield $17 \mathrm{~kg} /$ milking), or (2) nonreduced milking (NM; allowed up to 6 AMS milkings/d) and no maximum production. Feed and milking behavior data, as well as milk yield and SCC were collected from the AMS software. The RF cows had lower AMS feed delivered during the treatment period, as per the experimental design. Across the treatment period, the NF-NM cows had the highest milking frequency (2.7 times/d), followed by the RF-NM cows (2.4 times/d), and then both of the RM groups (1.8 times/d), which did not differ from each other. All cows, except the NF-NM cows, were gradually milked less frequently as dry-off approached. Across the entire 2-wk treatment period before dry-off, cows with RM allowance experienced a higher reduction in milk yield compared with the cows with no milking allowance
\end{abstract}

Received October 5, 2021.

Accepted December 2, 2021.

*Corresponding author: tdevries@uoguelph.ca restrictions ( -4.8 vs. $-3.6 \mathrm{~kg})$. Similarly, cows with a $\mathrm{RF}$ allocation tended to have a higher reduction in milk yield than cows with NF ( -4.6 vs. $-3.7 \mathrm{~kg}$ ). As result, those cows with both reduced milking permissions and feed allocation at the AMS experienced the greatest drop in milk production before dry-off. There were no differences between treatments for milking frequency or yield in the next lactation. Somatic cell score (calculated from SCC) was not different between treatments in the 2 -wk or day before dry-off, nor in the first month after calving. Overall, these data suggest that reducing both milking frequency and feed quantity in the AMS is the most efficient method to decrease milk yield before dry-off, without negatively influencing milking frequency or yield in the next lactation, as well as without affecting milk quality.

Key words: dry-off, robotic milking, production, health

\section{INTRODUCTION}

From the weeks after dry-off, when the mammary gland undergoes involution, to the onset of the next lactation with the proliferation of mammary epithelial cells and milk production, the cow is most susceptible to the occurrence of new IMI (Bradley and Green, 2004). Thus, management of the mammary gland is particularly important to properly set cows up for the next lactation and limit the occurrence of new cases of (sub)clinical mastitis (Bradley and Green, 2004). One of the strategies identified for reducing the risk of new IMI before dry-off and through the dry period is to reduce milk yield in the weeks leading up to dry-off (Gott et al., 2016). Milk yield before dry-off is a key factor affecting not only the susceptibility to IMI (RajalaSchultz et al., 2005), but also the potential for increased pain and discomfort around dry-off (Fogsgaard et al., 2012; Leslie and Petersson-Wolfe, 2012). Cows with a high milk yield at dry-off may have reduced lying time after drying off, because of udder discomfort, compared 
with lower-producing cows (Chapinal et al., 2014), and this may be especially true of cows that are dried off abruptly rather than gradually (Rajala-Schultz et al., 2018). Reducing milk yield before dry-off may, therefore, be beneficial for cow well-being. Gott et al. (2016) demonstrated that milk yield can be reduced up to $33 \%$ during the final week of lactation when milking frequency was reduced to 1 time/d compared with 2 times/d. In no study to date have any negative effects been demonstrated for reducing milking from 2 times/d to 1 time/d (Tucker et al., 2007, 2009) on cow health and behavior, implying that the benefits of reducing milk production before dry-off through reducing milking frequency is more beneficial than harmful. Another method to reduce milk yield before dry-off is to reduce dietary nutrient intake, ideally without inducing any level of hunger in cows, which could negatively affect cow welfare (Zobel et al., 2015).

In automated milking systems (AMS), it is possible to tailor the drying-off process to each individual cow, by adjusting both milking frequency and AMS feed supplement allocation. Because AMS concentrates are the main driving factor for cows to visit the AMS unit (Prescott et al., 1998), it may be strategic to reduce feed allocation to lower the quantity of energy offered to the cow and also reduce her motivation to visit the AMS. Indeed, it has been demonstrated for conventional milking that reducing feed allowance alone, instead of decreasing milking frequency, may be very effective at reducing milk production before dry-off and also reducing the occurrence of milk leakage and swelling (Tucker et al., 2009). Although some researchers have explored the effects of gradually reducing milk yield before dry-off through feeding and milking strategies on udder health and milk production in conventional milking systems (Tucker et al., 2009; Rajala-Schultz et al., 2018), we are not aware of any research to date on the implementation of these strategies before dry-off in farms using AMS.

Thus, the objective of this study was to determine how milking behavior, milk production, and SCC of dairy cows milked with an AMS are altered in response to changes in quantities of AMS pellet allocation and number of milkings allowed per day in the weeks leading up to dry-off. It was hypothesized that cows with a reduced AMS pellet allocation would have a decreased motivation to visit the AMS, thus reducing voluntary AMS visits and lowering milk yield. Also, it was hypothesized that a combination of reduced AMS feed allocation and reduced milking allowance would results in the greatest decrease in milk visits and yield in the 2 wk before dry-off. Finally, we hypothesized that reducing milk yield before dry-off would have no negative effects on milking activity, milk production, or milk quality after calving.

\section{MATERIALS AND METHODS}

\section{Animals, Housing, and Management}

A total of 445 lactating Holstein dairy cows were enrolled, including 182 primiparous and 263 multiparous cows (average parity $=2.05 \pm 0.21$; mean $\pm \mathrm{SD}$ ), from 5 commercial AMS dairy farms (Table 1) within 20 $\mathrm{km}$ of Saint-Hyacinthe (QC, Canada). The study was conducted between December 2018 and March 2020. Farms were selected as a convenience sample based on 2 criteria: proximity to the University of Montreal Saint-Hyacinthe campus and use of Lely Astronaut A4 AMS technology (Lely) to ensure consistency in treatment allocation and data collected. The use of these cows and experimental procedures complied with the guidelines of the Canadian Council on Animal Care (2009) and were approved by both the University of Guelph Animal Care Committee (AUP \#4119) and the Comité d'Éthique et d'Utilization des Animaux of the University of Montreal (\#18-Rech-1975). Cows averaged $332 \pm 64$ DIM and produced $25.4 \pm 11.9 \mathrm{~kg} / \mathrm{d}$ of milk at the time of enrollment into the study. The health status of cows was evaluated before recruitment, and if cows presented any signs of health problems, including but not limited to clinical mastitis, they were excluded from the study.

All farms had freestall housing with free-flow traffic access to the AMS, and cows had free access to water and lying space. All farms fed a partial mixed ration at the feed bunk, formulated to meet the energy and production requirements for the cows, as well as a concentrate, with $\sim 14 \% \mathrm{CP}$, at the AMS. Detailed management information such as lactating and dry cow diets, bedding and housing, as well as dry-off treatment protocol, for all 5 farms is included in Table 1. Herd size and number of AMS units per farm are included in Table 1.

On each farm, cows were dried off according to their expected calving date, as calculated by the Lely $\mathrm{T} 4 \mathrm{C}$ software (Time-for-Cows, Lely Industries NV), based on a predicted 60-d dry period. All farms had a farmspecific dry-off protocol that included some combination of intramammary antimicrobial prophylactic treatment and vaccination (Table 1 ).

\section{Experimental Design and Treatments}

Sample size calculations were based on (Morris, 1999) a target number of replicates needed per treatment 
France et al.: DRY-OFF MANAGEMENT IN AUTOMATED MILKING SYSTEMS

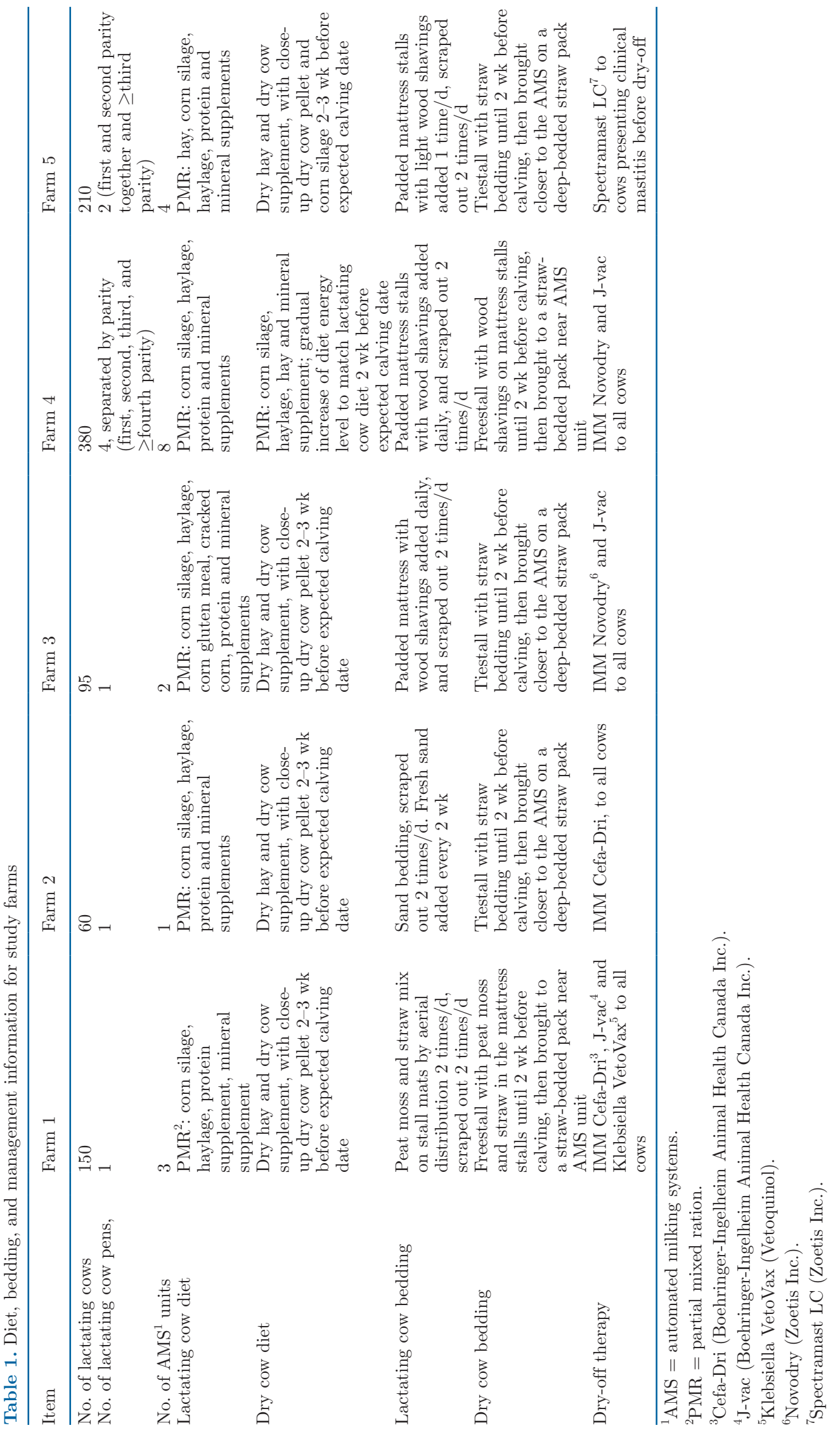


combination $(\mathrm{n}=110)$ to detect a $5 \%$ level of observed mean difference in milk yield reduction before dry-off, with a coefficient of variation of $18 \%$. The chosen study design was a randomized controlled trial with balanced random allocation of cows to all 4 treatment groups in each herd (Table 2). Cows were recruited 28 to $15 \mathrm{~d}$ before their planned dry-off date. Using a $2 \times 2$ factorial arrangement of treatments, applied from d 14 to 1 before dry-off, cows were randomly assigned within farm to either (1) reduced feed (RF) allowance [allowed $0.75 \mathrm{~kg} / \mathrm{d}$ of AMS pellet for the first week (14 to $8 \mathrm{~d}$ before dry-off) of treatment, and $0.50 \mathrm{~kg} / \mathrm{d}$ for the second week ( 7 to $1 \mathrm{~d}$ before dry-off) of treatment] or (2) nonreduced feed (NF) allowance (allowed up to $2 \mathrm{~kg} / \mathrm{d}$ of AMS pellet/d), and either reduced milking (RM) allowance (reduced to 2 milkings/d or as many times as required to yield $17 \mathrm{~kg} /$ milking), or nonreduced milking (NM) allowance (allowed up to 6 AMS milking visits/d). As a result, 4 treatment groups were created: (1) NF-NM ( $\mathrm{n}=117)$, (2) RF-RM ( $\mathrm{n}=103)$, (3) NFRM $(\mathrm{n}=120)$, and (4) RF-NM $(\mathrm{n}=105)$. For the RM group, rather than reducing every cow to 2 milkings/d, it was decided that a cut-off of milk production level be used in addition to the 2 times/d restriction, to prevent penalizing any high-producing cows, but keeping the milking frequency of lower-producing cows at or below 2 times/d. Thus, if a cow was expected to yield $\geq 17 \mathrm{~kg}$ at every milking according to the AMS algorithm, which calculates the expected yield, she could be milked even if it was more than 2 times/d. This was implemented to prevent excessive leakage or discomfort for those high-producing cows. Treatments were preprogrammed in the Lely T4C (Time-for-Cows, Lely Industries NV) software, using letters as identifiers (treatments A, B, $\mathrm{C}$, and $\mathrm{D}$ ), to which the research team and producers were blinded for the duration of the project. All cows had ad libitum access to the feed bunk where the partial mixed ration was offered to the milking herd on each respective farm. At all times, both during the treatment period, and after the dry period, all cows had to be milked a minimum of 1 time/d, without which the producer would receive an alert, and the cow would be fetched to be milked. After calving, across farms, the amount of feed provided in the AMS was allocated from a base amount of $2 \mathrm{~kg} / \mathrm{d}$ and increased in function with the amount of milk produced per day.

\section{Measuring Milk Yield, Milking Behavior, and SCC}

The AMS data from the T4C software (Lely Industries NV) on each farm's computer were downloaded every 2 mo. Extracted files included data on each visit to the AMS unit, with the cow number, lifetime number, date and time of visit, milk visit information

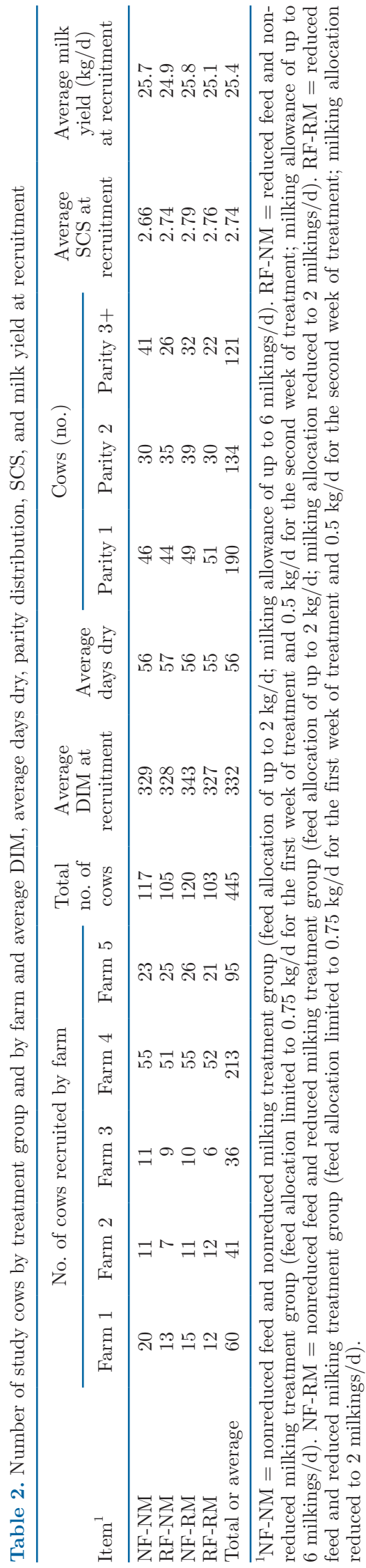


(successful milking, failure, or refusal), concentrate feed delivered, quarter-milk yield, and SCC. Somatic cell count was measured in the AMS with an integrated milk quality control-cell count sensor (Lely Industries NV), which uses a reagent mixed in with the milk extracted from each milking to measure gel viscosity, a similar process to the California Mastitis Test (Lusis et al., 2019). From those data, total daily milk yield $(\mathrm{kg})$, total daily AMS pellet delivered $(\mathrm{kg})$, and daily SCS were calculated for each cow. Total milk yield and pellet delivery were calculated by summing the milk yield or feed delivered at each milking into a daily total. Somatic cell score was calculated using the formula: $\log _{2}(\mathrm{SCC} / 100,000)+3$ (Wiggans and Shook, 1987), and was chosen to normalize the SCC data for statistical analyses. Milking behavior was defined in our study as the overall daily AMS visits, refusals, failures, and successful milkings, and these were calculated from the extracted AMS data. A visit was deemed a refusal if the cow was not milked because the minimal time between milkings had not elapsed. A failure occurred when one or more of the AMS milk cups did not stay attached for the entire duration of the milking, either due to being kicked, not being attached properly, or failure to find the teats. A successful milking was defined as one when a cow was milked out entirely, with no interruptions.

For the purpose of statistical analysis, a rolling 3-d average was computed for each of the milking-related variables, as this is a standard way of reporting milk yield for AMS (Deluyker et al., 1990). This serves to smooth out any short-term fluctuations in milking activity and milk yield, which tend to occur with AMS due to variable milking intervals across each 24 -h period. For the calculated reduction in milk yield over the treatment period, we used the rolling 3 -d average for $\mathrm{d}$ 14 minus the rolling 3 - $\mathrm{d}$ average for $\mathrm{d} 1$ before dry-off.

\section{Statistical Analyses}

Statistical analyses were conducted using SAS 9.4 (SAS Institute Inc.). A significance level of $P \leq 0.05$ was chosen, and tendencies were declared if $0.05<P \leq$ 0.10 . Three-way interaction terms with a $P$-value $\leq 0.05$ were retained in their respective models, otherwise those interaction terms were removed from the model. All data were assessed and confirmed for normality using the UNIVARIATE procedure of SAS.

To address our hypotheses, analyses were conducted to test the effects of the feeding (RF vs. NF) and milking (RM vs. NM) treatments, and their interaction on each of the outcome variables: milk yield, milking frequency, failures, refusals, and SCS. Separate analyses were conducted for the treatment period (the 2 -wk period before dry-off), the day before dry-off, as well as for the $28 \mathrm{~d}$ after the next calving. Data for the 2 -wk treatment period and $28 \mathrm{~d}$ after calving were each analyzed using a repeated measures general linear mixedeffect regression model using the MIXED procedure of SAS, treating day as a repeated measure. In each of these models, fixed effects were milking treatment, feeding treatment, milking treatment $\times$ feeding treatment interaction, and day. Due to differences in housing and management (including dry-off) between farms (Table 1), in our preliminary analysis, farm was tested as a fixed effect to determine, for the various outcome variables, if there were farm-specific interactions with the treatments; no interactions were detected, and, thus, farm was considered random for all analyses. Cow within herd, as subject of the repeated statement, was also considered random. For each model, the covariance structure with the best fit was selected, according to Schwarz's Bayesian information criterion; these covariance structures included compound symmetry and first-order autoregressive. Data for the day before dryoff and total reduction in milk yield across the treatment period were analyzed using a similar mixed-effect linear regression model as described above, with the exception of the inclusion of day as a repeated measure. For all models, when interactions were observed, the PDIFF procedure in the LSMEANS statement, with Tukey-Kramer adjustment, was used to investigate the differences in outcome values. Model fit was visually evaluated on the basis of the normality of the residual histogram plots, produced through use of the RESIDUAL option in the model statement.

\section{RESULTS}

\section{Milking Behavior and Production Before Dry-Off}

Effect of dry-off treatments on the milk production and behavior of Holstein dairy cows in the 14-d period before dry-off is presented in Table 3 . There was a day $\times$ feed treatment interaction for AMS feed delivered (Table 3), reflecting the fact that feed allocations were reduced for each day $(P<0.001)$ in the RF groups to a greater degree than the NF groups, particularly in the second week, as per the experimental design (Figure 1a). Furthermore, for the day before dry-off, RF cows had less feed delivered at the AMS compared with the NF cows (0.25 vs. $1.55 \mathrm{~kg} / \mathrm{d} ; \mathrm{SE}=0.09$; Table 3 ).

A 3-way interaction between day, milking treatment, and feeding treatment was present for milking frequency over the 2 -wk period before dry-off (Table 3 ). Specifically, during this period, the NF-NM cows had the highest milking frequency, followed by the RF-NM 
France et al.: DRY-OFF MANAGEMENT IN AUTOMATED MILKING SYSTEMS

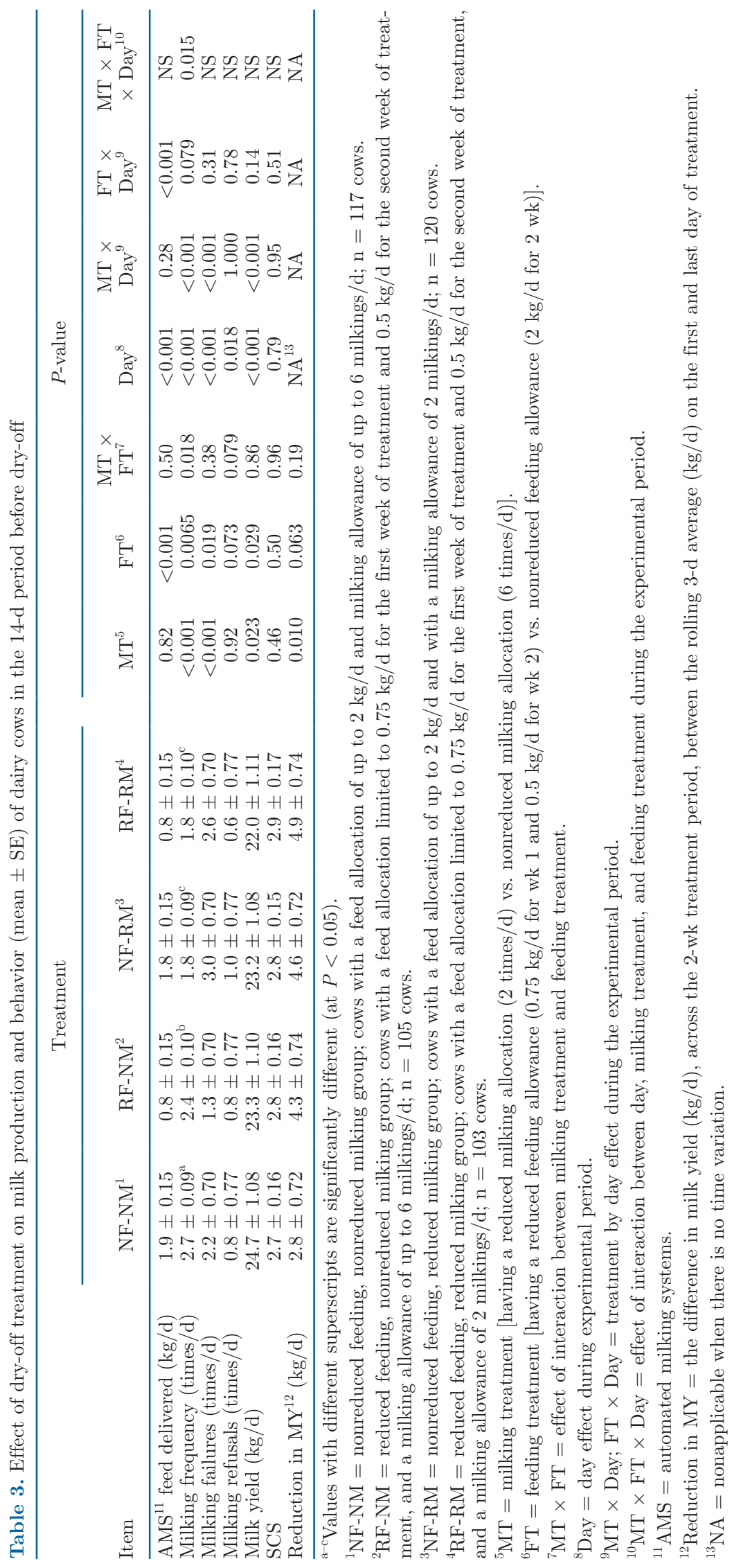



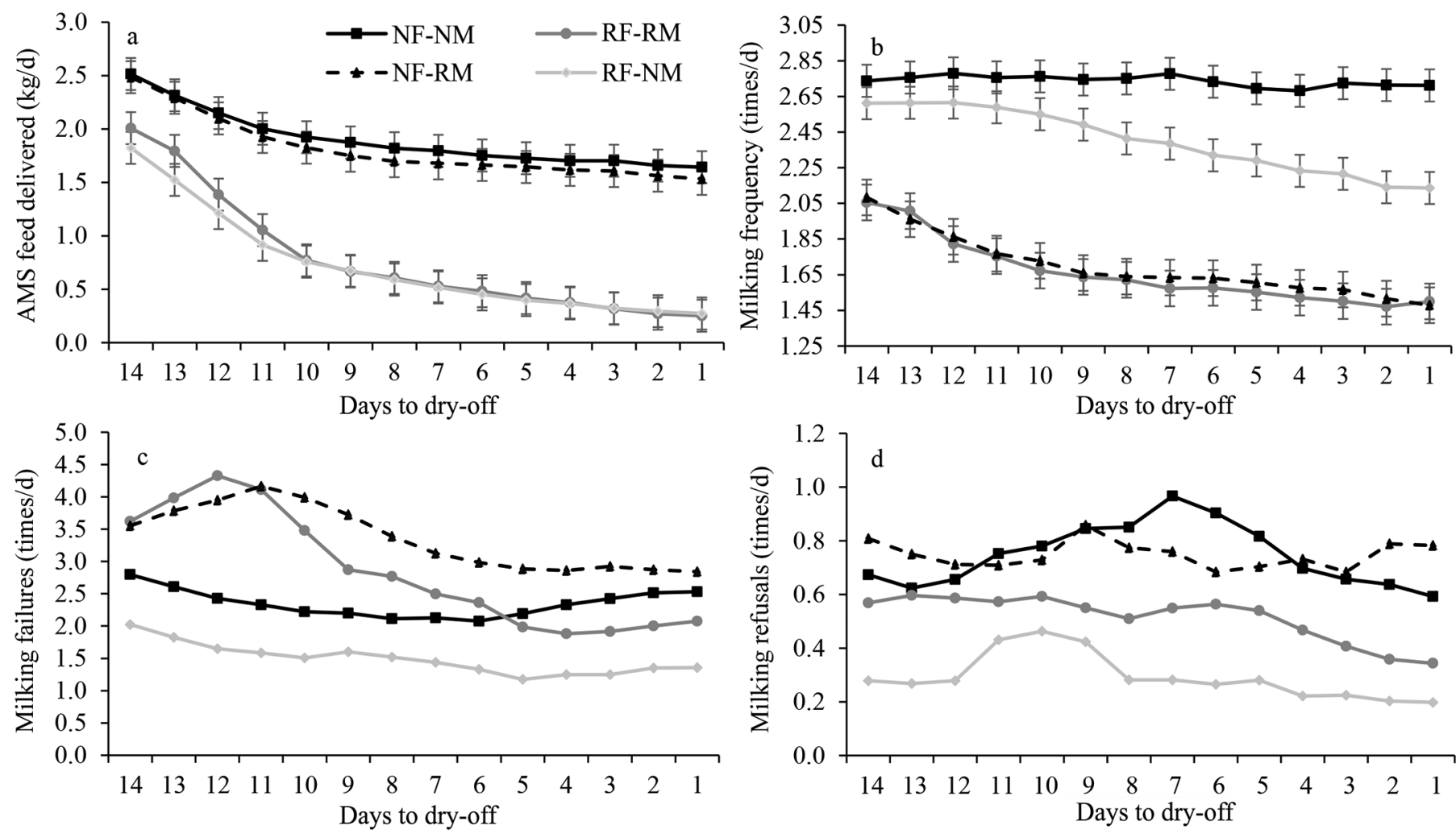

Figure 1. Average (a) automated milking systems (AMS) feed delivered (kg/d; $\pm \mathrm{SE}),(\mathrm{b})$ milking frequency (milkings/d; mean $\pm \mathrm{SE}$ ), (c) milking failures (times/d; SE $=0.70$ ), and (d) milking refusals (times/d; SE $=0.77$ ) by days to dry-off, for cows on 1 of 4 pre-dry-off milking and feeding treatment combinations: (1) NF-NM = nonreduced feed and nonreduced milking treatment group (feed allocation of up to $2 \mathrm{~kg} / \mathrm{d}$; milking allowance of up to 6 milkings/d; $\mathrm{n}=117$ ); (2) RF-NM = reduced feed and nonreduced milking treatment group (feed allocation limited to $0.75 \mathrm{~kg} / \mathrm{d}$ for the first week of treatment and $0.5 \mathrm{~kg} / \mathrm{d}$ for the second week of treatment; milking allowance of up to 6 milkings $/ \mathrm{d}$; $\mathrm{n}=105$ ) (3) NF-RM = nonreduced feed and reduced milking treatment group (feed allocation of up to $2 \mathrm{~kg} / \mathrm{d}$; milking allocation reduced to 2 milkings/d; $\mathrm{n}=120$ ); and (4) RF-RM = reduced feed and reduced milking treatment group (feed allocation limited to $0.75 \mathrm{~kg} / \mathrm{d}$ for the first week of treatment and $0.5 \mathrm{~kg} / \mathrm{d}$ for the second week of treatment; milking allocation reduced to 2 milkings $/ \mathrm{d} ; \mathrm{n}=103)$.

cows, and then both of the RM groups, which did not differ from each other (Figure 1b). All cows, except the NF-NM cows, experienced a gradual reduction in milking frequency as dry-off approached. The NF-NM cows experienced no change in milking frequency over the 2-wk treatment period (Figure 1b). Overall, cows in the NM group were milked more often than the RM cows, for all $15 \mathrm{~d}(P<0.001)$ (Figure 1b). A difference in milking frequency was detected $(P=0.002)$ between the NF-NM and RF-NM cows across the 2-wk period before dry-off. One day before dry-off, we observed a milk treatment by feeding treatment interaction for milking frequency (Table 3); specifically, cows in the RM group had the lowest milking frequency $1 \mathrm{~d}$ before dry-off $(1.55 \times / \mathrm{d} ; \mathrm{SE}=0.10$; Table 3$)$, whereas NM cows had higher milking frequency. Further, among the NM treatment, the NF-NM cows had a higher milking frequency than the RF-NM cows on that day (Table 3).

In the 2-wk period before dry-off, there was an interaction between milking treatment and day for milking failures (Table 3); the frequency of milking failures from d 14 to $6(P<0.006)$ before dry-off was higher in the RM cows compared with the NM cows (Figure 1c). Further, a decrease in the number of failures was observed for the RM cows after d 11 before dry-off (Figure 1c). Overall, the RF groups experienced a lower number of failures per day compared with the NF cows (2.0 vs. 2.6 times $/ \mathrm{d}, \mathrm{SE}=0.70$; Table 3$)$. In the $1 \mathrm{~d}$ before dry-off, the RF cows had fewer milking failures than the NF cows (Table 4; 1.35 vs. 2.4 failures/d; SE $=0.60)$.

Over the 2-wk period before dry-off milking refusal frequency varied by day (Table 3), with no obvious trend (Figure 1d). Number of milking refusals tended to be lower for RF cows compared with NF cows (Table 3 ). This effect was more pronounced on the day before dry-off, where RF cows had fewer milking refusals than NF cows (0.55 vs. 0.85 failures/d; $\mathrm{SE}=0.65$; Table 4).

In the 2 wk before dry-off, milk yield declined for cows on all treatments (Figure 2). During this time, 
the effect of milk treatment on milk yield varied by day (Table 3). Cows with RM had lower milk yield compared with the NM cows across all days before dry-off $(P \leq 0.023)$, except the first $2 \mathrm{~d}$ of treatment $(\mathrm{d} 13$ and $14 ; P \geq 0.20$; Figure 2). Across the whole 2 -wk treatment period, RF cows had lower milk yield compared with NF cows (22.7 vs. $24.0 \mathrm{~kg} / \mathrm{d}$; SE = 1.08; Table 3).

Across the entire 2-wk treatment period before dryoff, RM cows experienced a higher reduction in milk yield compared with the cows with no milking allowance restrictions $(-4.8$ vs. $-3.6 \mathrm{~kg} ; \mathrm{SE}=0.90$; Table 3 ; Figure 2). Similarly, RF cows tended to have a higher reduction in milk yield than NF cows $(-4.6$ vs. -3.7 $\mathrm{kg}$; $\mathrm{SE}=0.73$; Table 3). Overall, RF-RM cows experienced the greatest reduction in milk production before dry-off (Table 3; Figure 2).

Milk yield on the day before dry-off was higher for the NF and NM cows compared with RF and RM cows, respectively (Table 4), such that it was highest for the NF-NM cows and lowest for RF-RM cows (Figure 2).

Somatic cell scores did not significantly differ among treatments in the 2 wk before dry-off (Table 3). Similarly, SCS did not differ among treatment groups in the day before dry-off (Table 4).

\section{Milking Behavior and Production 28 Days After Calving}

In the 28-d period after calving, there were no significant differences detected in quantity of AMS pellet delivered $(\mathrm{kg} / \mathrm{d})$ among treatment groups; however, there was a significant day effect (Table 5): feed allocation increased as DIM increased (Figure 3a). For that same time period, there were also no differences between treatments in milking frequency, milking refusals, and milking failures (Table 5). Milking frequency varied by DIM but increased steadily until 17 DIM for all cows, after which it stayed constant (Figure 3b). A day effect was also observed for milking failures, with a rapid increase in the first 8 DIM across all treatment groups, before decreasing to a steady number of failures per day by 28 DIM (Figure 3c). Similarly, across all groups, a day effect was observed for milking refusals (Table 5), with the number of refusals per day increasing until 4 DIM, before decreasing to a constant level by 28 DIM (Figure 3d). Despite a milk treatment by feed treatment interaction (Table 5), no differences in milk yield were detected between individual treatment groups in the 28-d period after calving. As displayed in Figure 4, milk yield increased rapidly for the first 7 DIM and then increased more slowly until the end of the 28-d period. There was no significant effect of treatment on SCS in $28 \mathrm{~d}$ after calving, but there was an increase in SCS as DIM increased (Table 5). Somatic cell score increased rapidly in the $8 \mathrm{~d}$ after calving and then gradually decreased over the first month of lactation (data not shown).

\section{DISCUSSION}

To address our objective, in the 2-wk time period before dry-off, AMS cows were either assigned to a re-

Table 4. Effect of dry-off treatment on the milk production and behavior (mean $\pm \mathrm{SE}$ ) of dairy cows in the last day before dry-off

\begin{tabular}{|c|c|c|c|c|c|c|c|}
\hline Item & \multicolumn{4}{|c|}{ Treatment } & \multicolumn{3}{|c|}{$P$-value } \\
\hline $\mathrm{AMS}^{8}$ feed delivered $(\mathrm{kg} / \mathrm{d})$ & $1.6 \pm 0.08$ & $0.2 \pm 0.09$ & $1.5 \pm 0.08$ & $0.3 \pm 0.09$ & 0.57 & $<0.001$ & 0.17 \\
\hline Milking failures (times/d) & $2.3 \pm 0.59$ & $1.0 \pm 0.60$ & $2.6 \pm 0.59$ & $1.7 \pm 0.60$ & 0.31 & 0.0039 & 0.16 \\
\hline Milking refusals (times/d) & $0.7 \pm 0.65$ & $0.6 \pm 0.65$ & $1.0 \pm 0.65$ & $0.5 \pm 0.65$ & 0.88 & 0.030 & 0.14 \\
\hline Milk yield $(\mathrm{kg} / \mathrm{d})$ & $23.7 \pm 1.03$ & $21.5 \pm 1.06$ & $21.6 \pm 1.03$ & $20.2 \pm 1.06$ & 0.008 & 0.0048 & 0.54 \\
\hline
\end{tabular}

${ }^{\mathrm{a}-\mathrm{c}}$ Values with different superscripts are significantly different (at $P<0.05$ ).

${ }^{1} \mathrm{NF}-\mathrm{NM}=$ nonreduced feeding, nonreduced milking group; cows with a feed allocation of up to $2 \mathrm{~kg} / \mathrm{d}$ and milking allowance of up to 6 milkings/d; $\mathrm{n}=117$ cows.

${ }^{2} \mathrm{RF}-\mathrm{NM}=$ reduced feeding, nonreduced milking group; cows with a feed allocation limited to $0.75 \mathrm{~kg} / \mathrm{d}$ for the first week of treatment and 0.5 $\mathrm{kg} / \mathrm{d}$ for the second week of treatment, and a milking allowance of up to 6 milkings $/ \mathrm{d} ; \mathrm{n}=105$ cows.

${ }^{3} \mathrm{NF}-\mathrm{RM}=$ nonreduced feeding, reduced milking group; cows with a feed allocation of up to $2 \mathrm{~kg} / \mathrm{d}$ and with a milking allowance of 2 milkings/d; $\mathrm{n}=120$ cows.

${ }^{4} \mathrm{RF}-\mathrm{RM}=$ reduced feeding, reduced milking group; cows with a feed allocation limited to $0.75 \mathrm{~kg} / \mathrm{d}$ for the first week of treatment and $0.5 \mathrm{~kg} / \mathrm{d}$ for the second week of treatment, and a milking allowance of 2 milkings/d; $\mathrm{n}=103$ cows.

${ }^{5} \mathrm{MT}=$ milking treatment [having a reduced milking allocation $(2$ times $/ \mathrm{d})$ vs. nonreduced milking allocation $(6$ times/d)].

${ }^{6} \mathrm{FT}=$ feeding treatment [having a reduced feeding allowance $(0.75 \mathrm{~kg} / \mathrm{d}$ for wk 1 and $0.5 \mathrm{~kg} / \mathrm{d}$ for wk 2$)$ vs. nonreduced feeding allowance $(2$ $\mathrm{kg} / \mathrm{d}$ for $2 \mathrm{wk})]$.

${ }^{7} \mathrm{MT} \times \mathrm{FT}=$ effect of interaction between milking treatment and feeding treatment.

${ }^{8} \mathrm{AMS}=$ automated milking systems. 


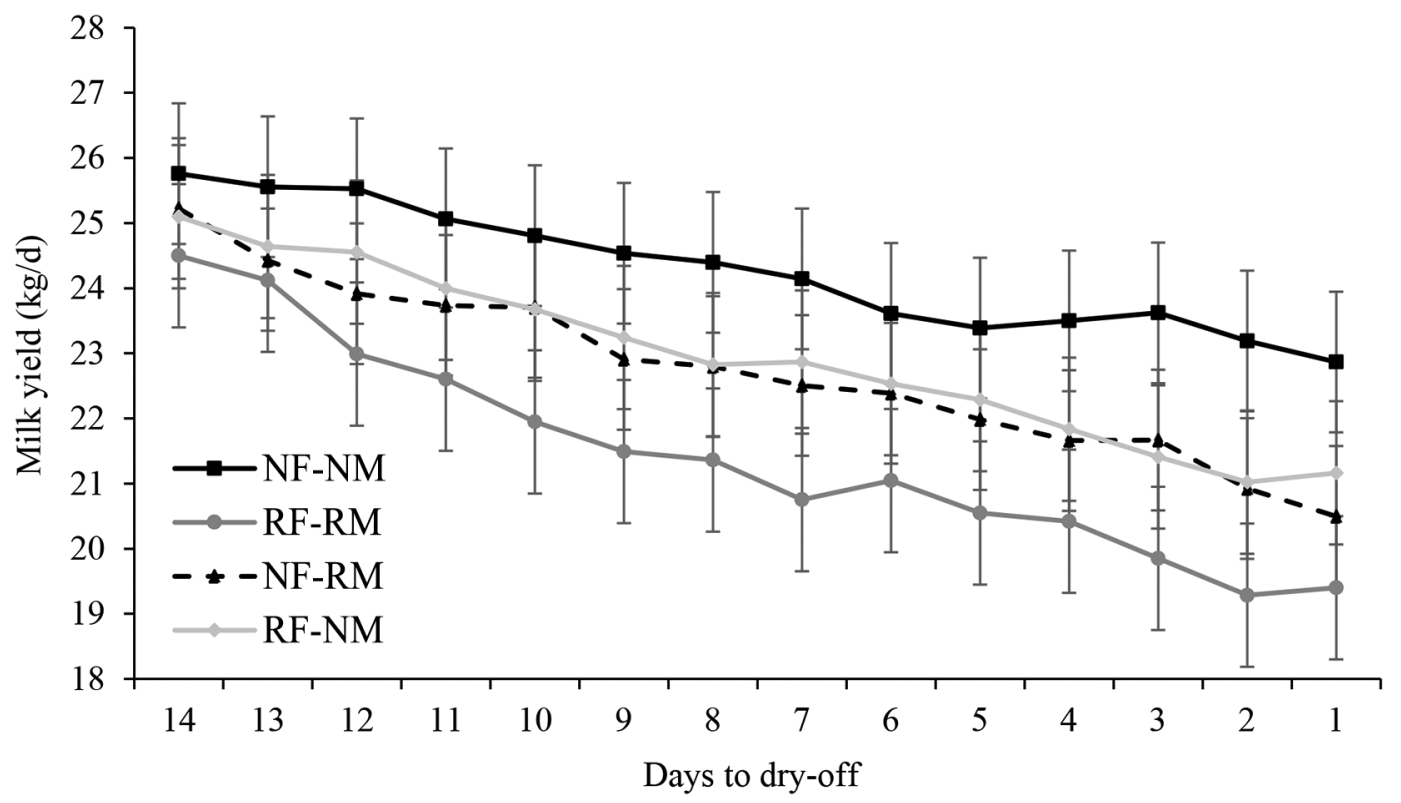

Figure 2. Average $( \pm \mathrm{SE})$ milk yield $(\mathrm{kg} / \mathrm{d})$ by days to dry-off, for cows on 1 of 4 pre-dry-off milking and feeding treatment combinations: $(1)$ $\mathrm{NF}-\mathrm{NM}=$ nonreduced feed and nonreduced milking treatment group (feed allocation of up to $2 \mathrm{~kg} / \mathrm{d}$; milking allowance of up to 6 milkings/d; $\mathrm{n}$ $=117$ ); (2) RF-NM = reduced feed and nonreduced milking treatment group (feed allocation limited to $0.75 \mathrm{~kg} / \mathrm{d}$ for the first week of treatment and $0.5 \mathrm{~kg} / \mathrm{d}$ for the second week of treatment; milking allowance of up to 6 milkings $/ \mathrm{d} ; \mathrm{n}=105$ ); (3) NF-RM = nonreduced feed and reduced milking treatment group (feed allocation of up to $2 \mathrm{~kg} / \mathrm{d}$; milking allocation reduced to 2 milkings $/ \mathrm{d} ; \mathrm{n}=120$ ); and (4) RF-RM $=$ reduced feed and reduced milking treatment group (feed allocation limited to $0.75 \mathrm{~kg} / \mathrm{d}$ for the first week of treatment and $0.5 \mathrm{~kg} / \mathrm{d}$ for the second week of treatment; milking allocation reduced to 2 milkings/d; $\mathrm{n}=103)$.

duced or nonreduced level of AMS feed provision and also to either a RM or NM allowance at the AMS. By design, we succeeded in decreasing AMS feed delivered by changing the feed settings in the AMS, with the RF cows receiving fewer pellets than the NF cows $(0.80$ vs. $1.85 \mathrm{~kg} / \mathrm{d}$ ) over the entire 2 -wk period. The difference in feed allocated between the RF and NF groups was smaller in the first days after the onset of treatment compared with later in the treatment period. This can be explained by the AMS adjusting from the baseline feed quantity received to the experimental quantity. The AMS adjusts feed quantities over several (3-4) days, to avoid drastic changes in feed allocation. The AMS feed allocation also decreased further in the RF group after d 8 before dry-off, as per the treatment design imposed on the RF cows, who went from 0.75 to $0.50 \mathrm{~kg} / \mathrm{d}$ on d 7 before dry-off.

Due to the experimental design, the RM groups had less frequent milkings than the NM groups, which was to be expected. There was, however, a difference in milking frequency between the NM groups. The NFNM cows did not experience a reduction in milking frequency and had the highest number of milkings per day, which remained steady throughout the entire 2-wk period. Alternatively, the RF-NM cows had reduced milking frequency, as compared with the NF-NM cows, by $10 \mathrm{~d}$ before dry-off ( $4 \mathrm{~d}$ after the onset of treatment). Conversely, cows on the RM treatments had reduced milking frequency over the 2 -wk treatment period, not differing from each other over the 2 wk. From this, we can conclude that simply reducing the amount of pellet offered in the AMS is enough to reduce milking frequency, as cows may experience a reduced motivation to visit the AMS, due to there being less available pellet. Because feed is one of the primary reasons for cows to visit the AMS (Prescott et al., 1998), a RF allowance likely explains the decrease in milking frequency, which in turn led to reduced milk yield. Reduced milking frequency in the RM groups is explained by the AMS settings, which limited cow milking permissions in the AMS. However, what is not explained is why the RFRM cows did not have a reduced milking frequency compared with the NF-RM cows, due to the potential additive effect of the reduced AMS feed allowance. A plausible explanation is that the minimum number of milkings had already been reached, because we set a minimum number of milkings at 1 time/d, or if cows would give $>17 \mathrm{~kg}$ per milking as per our calculated allowance for high-producing cows (who were allowed more than 2 milkings/d), which may have limited how much we could lower milking frequency in either of these groups. To assess this, we would have had to not 
France et al.: DRY-OFF MANAGEMENT IN AUTOMATED MILKING SYSTEMS

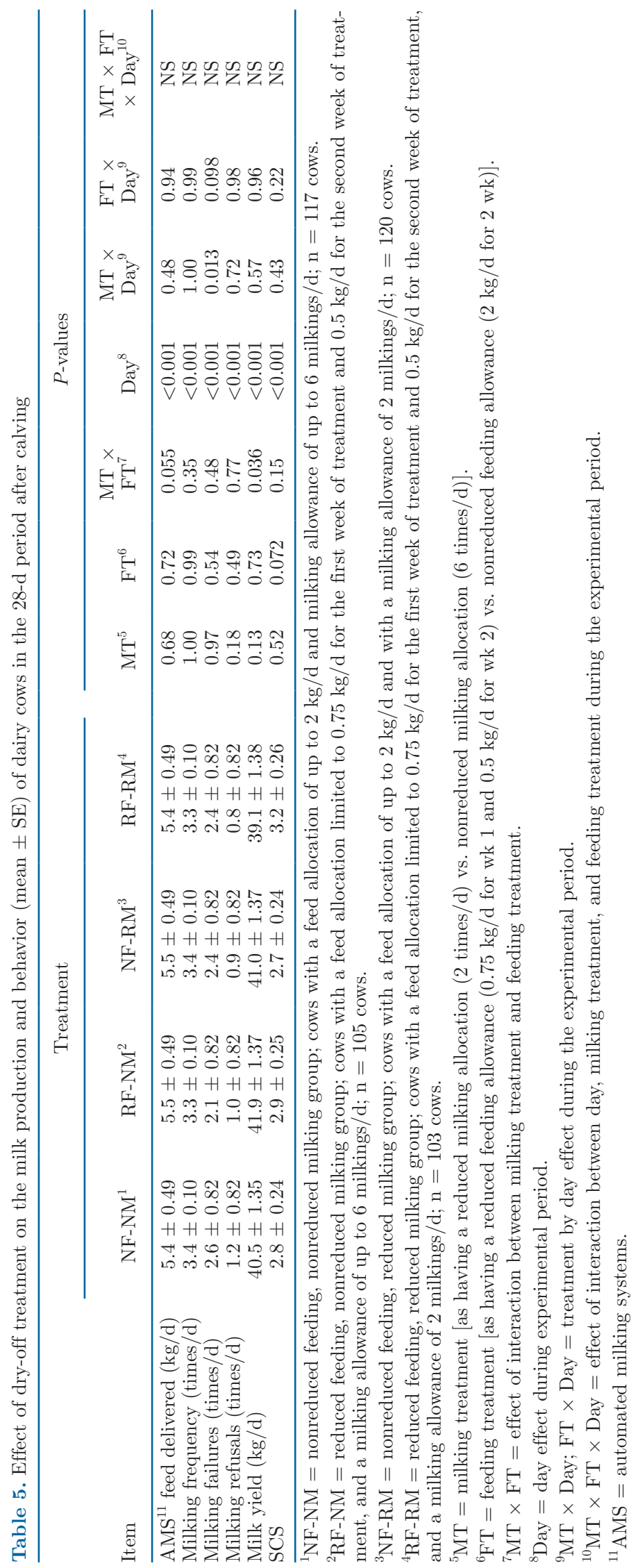



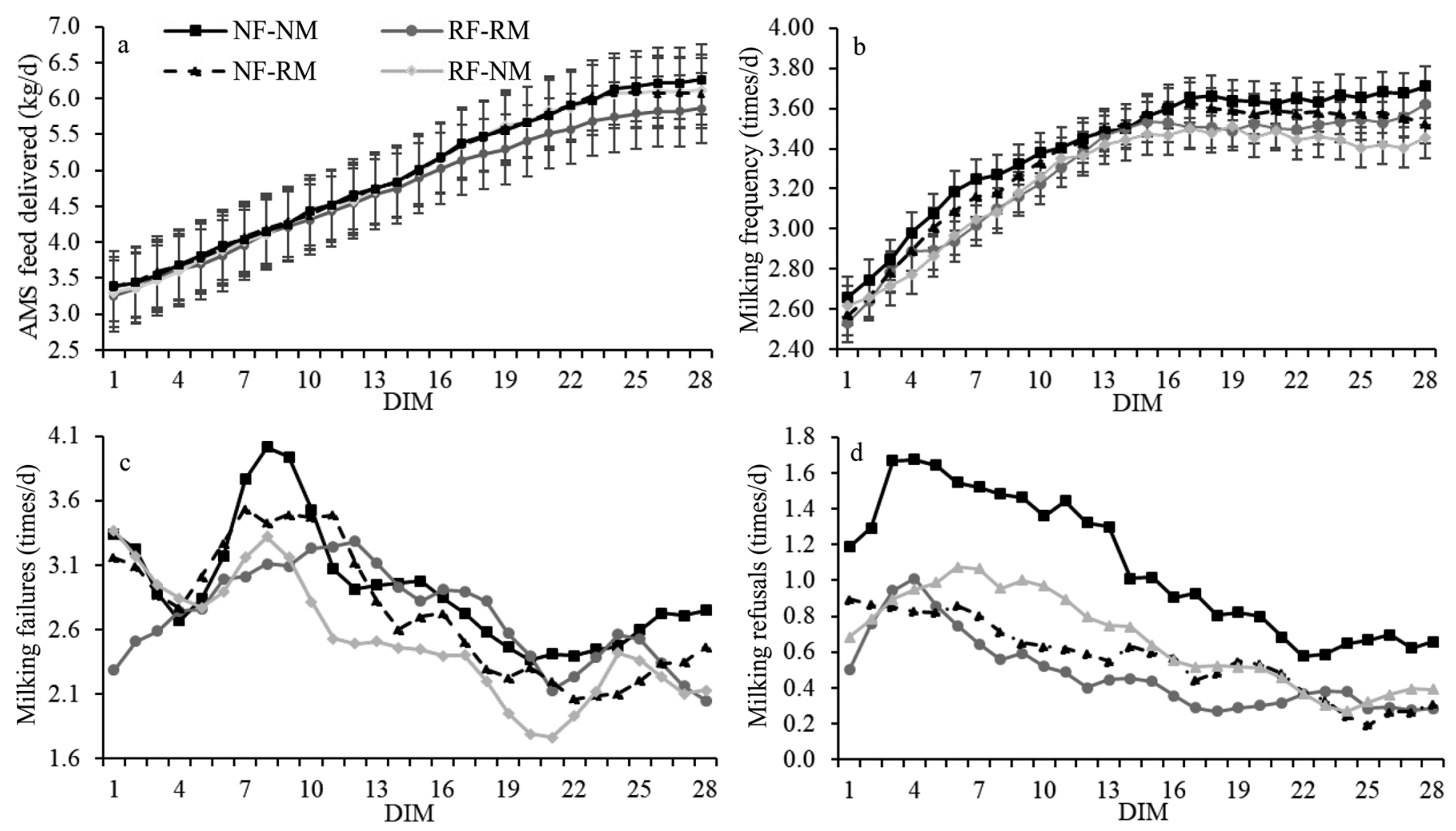

Figure 3. Average (a) automated milking systems (AMS) feed delivered (kg/d; \pm SE), (b) milking frequency (milkings/d; \pm SE), (c) milking failures (times/d; SE $=0.82$ ), and (d) milking refusals (times/d; $\mathrm{SE}=0.82$ ), in the first $28 \mathrm{~d}$ after calving, for cows on 1 of 4 pre-dry-off milking and feeding treatment combinations: (1) NF-NM = nonreduced feed and nonreduced milking treatment group (feed allocation of up to 2 $\mathrm{kg} / \mathrm{d}$; milking allowance of up to 6 milkings/d; $\mathrm{n}=117$ ); (2) RF-NM = reduced feed and nonreduced milking treatment group (feed allocation limited to $0.75 \mathrm{~kg} / \mathrm{d}$ for the first week of treatment and $0.5 \mathrm{~kg} / \mathrm{d}$ for the second week of treatment; milking allowance of up to 6 milkings/d; $\mathrm{n}$ $=105$ ); (3) NF-RM = nonreduced feed and reduced milking treatment group (feed allocation of up to $2 \mathrm{~kg} / \mathrm{d}$; milking allocation reduced to 2 milkings/d; $\mathrm{n}=120$ ); and (4) RF-RM = reduced feed and reduced milking treatment group (feed allocation limited to $0.75 \mathrm{~kg} / \mathrm{d}$ for the first week of treatment and $0.5 \mathrm{~kg} / \mathrm{d}$ for the second week of treatment; milking allocation reduced to 2 milkings $/ \mathrm{d} ; \mathrm{n}=103$ ).

impose a minimum number of milkings per day; this was not possible as the cows used in this study were from commercial farms where the producers did not want cows to go unmilked for long periods (i.e., more than $24 \mathrm{~h})$.

A higher number of milking failures was observed for the cows with RM permissions compared with the cows with no permission restrictions (NM), in the first $5 \mathrm{~d}$ of treatment, after which they decreased and stabilized, and were similar to the NM cows. This might have been expected for refusals, because cows with free access to the AMS unit during their lactation might have increased motivation to keep going to the AMS to be milked more than twice a day if a restriction was imposed. However, an elevation in failures is difficult to explain, because failures are normally attributed to improper teat-cup attachment, an unruly cow kicking off a milker, or a human intervention leading to a failed milking, and none of these can be directly explained by a reduced number of milkings per day. One possible reason for a failure is improper teat-cup attachment that would occur in the instance where a cow's udder is more engorged or asymmetrical, due to a longer interval between milkings, for example due to milking permission restrictions. This could explain why the RM cows had more failures than the other cows, as this was shortly after the treatment was imposed and milking frequency declined most rapidly, which could possibly have led to engorgement of the udder. This is similar to Hovinen et al. (2005), who demonstrated that irregularshaped or engorged udders were not cleaned properly compared with normal udders, when comparing teat brush efficiency in AMS. More research is needed to determine if the effect on failures in our study is related to the experimental design, or another unexplained factor.

The tendency for a difference in milking refusals between the NF and RF cows before dry-off was more pronounced on the final day before dry-off and was 
different than expected. An increase in refusals earlier in the treatment period would be hypothesized for cows with restricted feed access, because their motivation for feed would have remained high after the onset of the treatment period, going back to the primary reason for cows to visit the AMS. This might lead us to believe that cows quickly lose interest in going to the AMS when they learn that pellet allocation is reduced. Prescott et al. (1998) demonstrated that high-yielding cows visited an AMS unit more often when fed a higher amount of pellet than when they were not fed, but always chose to be fed rather than be milked when tested in a Y-maze type of experiment with option of visiting a feed bucket or an AMS. This indicates that cows are motivated both for feed and for being milked, but that the motivation to be fed is greater than to be milked (Prescott et al., 1998). More research is needed to properly identify the importance of being fed, as compared with being milked, in late lactation cows in AMS herds.

The combined effects of reduced milking frequency and feed delivery at the AMS resulted in the largest decrease in milk yield across the 2-wk period before dry-off. Furthermore, cows on just the RF or RM treatment had lower milk yield than cows with no restrictions imposed. This demonstrates that reducing milking permissions in the AMS helps reduce milk yield before dry-off. To our knowledge, this is the first study in AMS to document this effect. Our results are consistent with Gott et al. (2016), who demonstrated that cows milked in a parlor 1 time/d for a week before dry-off had a $33 \%$ reduction in milk compared with cows with no change in milking schedule (2 times/d). Rajala-Schultz et al. (2018) also demonstrated a similar effect for cows milked in a parlor only once a day instead of 3 times/d in the last week before dry-off, with cows on the reduced milking treatment experiencing a significant decrease in milk production before dry-off.

In our study, decreasing feed allowance in the AMS also helped reduce milk yield, which could be due to cows consuming less nutrients with the reduction in feed delivered through the AMS (Shortall et al., 2018), from a decreased motivation to visit the AMS due to the lower quantity of feed offered (Prescott et al., 1998), or from a combination of both of these factors. The RF-RM had the greatest overall reduction in milk yield over the 2-wk period, as well as the lowest average milk yield the day before dry-off, indicating that this would be the most efficient strategy in AMS for reducing milk yield before dry-off. This is supported by Tucker et al. (2009), who demonstrated that decreasing feed allowance and milking frequency (from 2 to 1 time/d) before dry-off helped to reduce milk yield. Although the feed

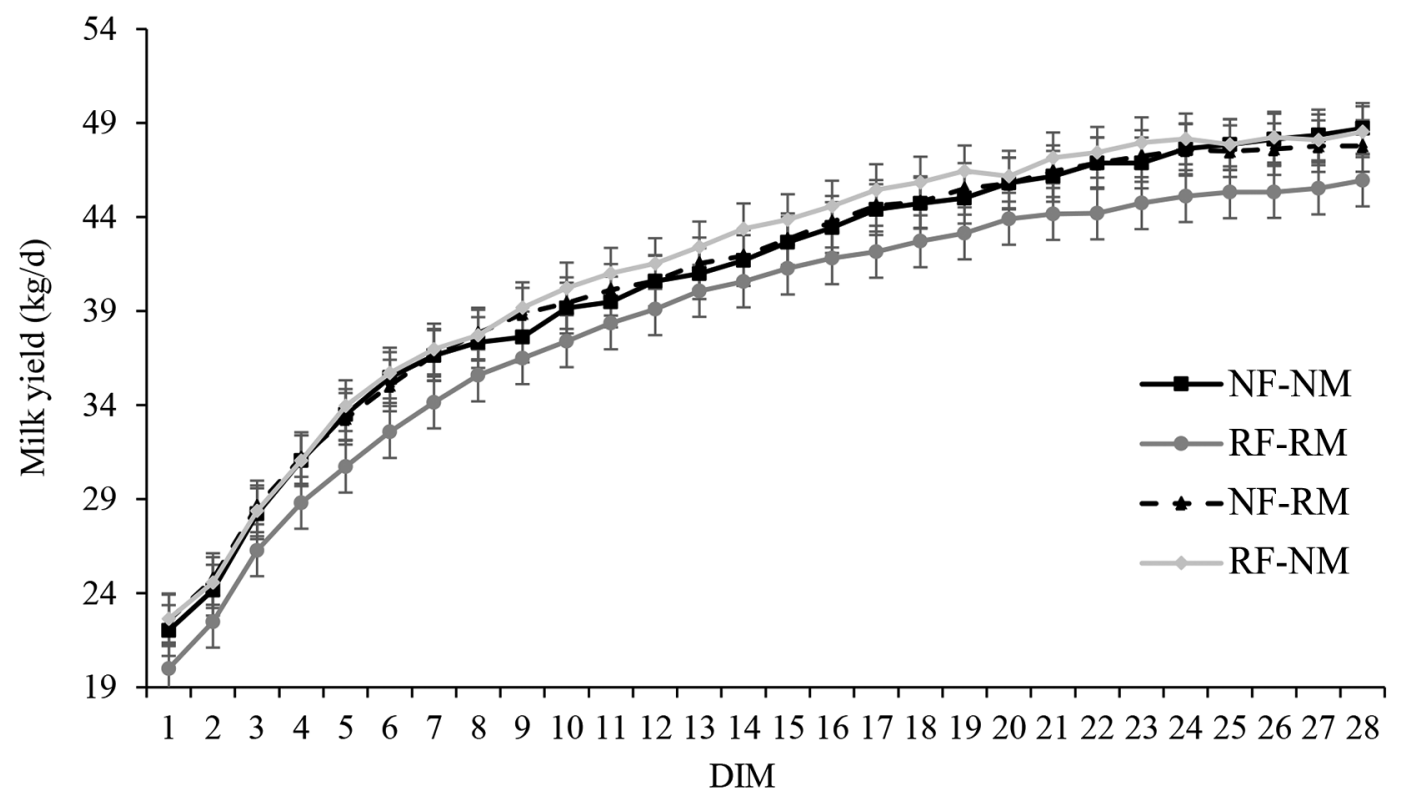

Figure 4. Average $( \pm \mathrm{SE})$ milk yield $(\mathrm{kg} / \mathrm{d})$ in the first $28 \mathrm{~d}$ after calving, for cows on 1 of 4 pre-dry-off milking and feeding treatment combinations: (1) NF-NM = nonreduced feed and nonreduced milking treatment group (feed allocation of up to $2 \mathrm{~kg} / \mathrm{d}$; milking allowance of up to 6 milkings/d; $\mathrm{n}=117$ ); (2) RF-NM = reduced feed and nonreduced milking treatment group (feed allocation limited to $0.75 \mathrm{~kg} / \mathrm{d}$ for the first week of treatment and $0.5 \mathrm{~kg} / \mathrm{d}$ for the second week of treatment; milking allowance of up to 6 milkings $/ \mathrm{d} ; \mathrm{n}=105)$; (3) NF-RM = nonreduced feed and reduced milking treatment group (feed allocation of up to $2 \mathrm{~kg} / \mathrm{d}$; milking allocation reduced to 2 milkings/d; $\mathrm{n}=120$ ); and (4) RF$\mathrm{RM}=$ reduced feed and reduced milking treatment group (feed allocation limited to $0.75 \mathrm{~kg} / \mathrm{d}$ for the first week of treatment and $0.5 \mathrm{~kg} / \mathrm{d}$ for the second week of treatment; milking allocation reduced to 2 milkings/d; $\mathrm{n}=103$ ). 
restriction in that study was applied by reducing pasture and pasture silage access, the ultimate goal was to reduce total DMI, and indirectly energy provided, which is similar to how we reduced feed by reducing the amount of AMS pellet offered. In our study, the RFNM and NF-RM groups had a similar total reduction in milk yield over the 2 -wk period $(-4.3 \mathrm{~kg}$ and -4.6 $\mathrm{kg}$, respectively), indicating that either one of these strategies alone is similarly efficient at reducing milk yield in the 2-wk before dry-off.

No differences were detected between treatment groups for SCS in the weeks leading up to dry-off, nor was there any change in SCS over the 2 -wk treatment period. This did not differ from what we expected, because we aimed to experimentally reduce milk yield before dry-off, without having a negative effect on udder health. This is consistent with a similar study by Rajala-Schultz et al. (2018), where they reported no difference in the $\log \mathrm{SCC}$ on the last test-day before dry-off between those cows abruptly dried off and those gradually dried off. There is, therefore, no indication that udder health was affected by the treatments included in our study.

This study was the first, to our knowledge, to investigate the effect of manipulating milking frequency and feed allowance before drying off on production and behavioral outcomes in AMS cows in the postcalving period. Overall, there were no detected carry-over effects of pre-dry-off treatment on any of the milking behavior and production variables. This is consistent with Zobel et al. (2013), who demonstrated that parlor-milked cows on either a gradual or abrupt dry-off schedule had similar SCS levels postcalving. However, in a more recent observational study of AMS-milked cows, at the univariable level, cows that were dried off with some type of gradual method tended to have lower SCC after calving compared with cows dried off abruptly (Padua et al., 2021). However, in their multivariable model, those researchers only reported SCC after calving to be associated with SCC before drying off, reaffirming that an important way of promoting low SCC levels after calving is to ensure cows are dried off at a low SCC level. Similar to our results, Gott et al. (2017) also demonstrated that method of cessation of milking for parlor-milked cows did not influence milk yield in the subsequent lactation. In a similar fashion to our study, Padua et al. (2021) demonstrated that postcalving behavior and performance of cows was more likely to be associated with past performance, rather than with the method of dry-off.

The daily changes in milking behavior and yield we observed in the first 28 DIM are expected, given that at the onset of lactation, feed intake, milking frequency, and milk yield increase as DIM increase (Siewart et al., 2019). Indeed, we demonstrated that milk yield and milking frequency followed a familiar trend of increasing as DIM increased. Other researchers have also reported that milking frequency and milk yield are correlated, both as a way for the udder to adapt to greater demand as the udder is emptied more regularly (Dahl et al., 2004). Although, in the current study, milk yield continued to increase past 17 DIM, milking frequency seemed to stabilize; this could be due to cows not being able to visit the AMS more than a certain number of times a day due to traffic, robot settings, and the biological need to do something else than being milked (laying down, resting, eating, or drinking). Feed allocation at the AMS also increased in the first $2 \mathrm{wk}$ of lactation, after which it plateaued. This is attributable to the fact that as the number of cows' visits increased, so would have the amount of pellet they received up to the maximum daily amount programmed for them. When the number of milkings per day steadied after 2 wk in milk, so did the feed allocation. Somatic cell score increased in the first few days of lactation, but then settled to lower, steady values, similar to pre-dry-off levels by $10 \mathrm{~d}$ postcalving. This is consistent with the literature, as researchers have previously demonstrated that SCC tends to be higher in the first few days after calving, before decreasing to steady levels by 21 DIM (Barkema et al., 1999; Graesboll et al., 2016).

There were some unpredicted changes in milking refusals and failures in early lactation. Milking refusals increased in the first week and then dropped down after 7 DIM, to remain steady after 14 DIM. This could be due to cows being more agitated after calving and having increased activity from lying less (Maselyne et al., 2017) or searching for high-energy grain to satisfy their increased demand in energy from milk production (Bewley et al., 2010). As for milking failures, which followed a similar trend as refusals over the first few weeks of lactation, this could rather be due to the AMS not being able to attach properly to the udder because of edema, which occurs naturally at the onset of lactation (Knight and Wilde, 1993). This is speculative, however, as to our knowledge, there are no published data on how milking failures and refusals evolve over the early lactation period in AMS cows. More research is, thus, needed, to further investigate which factors may influence these milking-related outcomes in early lactation.

\section{CONCLUSIONS}

Cows with reduced AMS feed allocation and reduced milking permissions in the AMS unit for the 2-wk period before dry-off had the greatest decline in milk yield 
over that time period and the least milk yield at dryoff. We demonstrated that reducing either the milking allowance or the feeding allocation at the AMS alone were also efficient at decreasing milk yield before dryoff, but to a lesser extent than using both strategies. These reductions in milk yield to facilitate dry-off were achieved without having a negative effect on milking behavior, SCS, or milk yield in the early weeks of the subsequent lactation.

\section{ACKNOWLEDGMENTS}

The authors thank the producers who allowed us to sample milk from their cows, and who helped us when needed. We thank Caroline Forest, Mélissa Desautels, Caroline Chénard, and Jean-Philippe Pelletier, who helped with sample collection and analysis at the University of Montreal (Saint-Hyacinthe, QC, Canada), as well as Meagan King (University of Manitoba, Winnipeg, MB, Canada) for her assistance with the statistical portion of this paper. This research was supported by a contribution from the Dairy Research Cluster 3 [Dairy Farmers of Canada (Ottawa, ON, Canada) and Agriculture and Agri-Food Canada (Ottawa, ON, Canada)] under the Canadian Agricultural Partnership AgriScience Program, and through the Mastitis Network (Saint-Hyacinthe, QC, Canada). The first author was also supported by means of the Natural Sciences and Engineering Research Council of Canada (NSERC; Ottawa, ON, Canada) CREATE in Milk Quality Program, administered by the Mastitis Network (SaintHyacinthe, QC, Canada). The authors have not stated any conflicts of interest.

\section{REFERENCES}

Barkema, H. W., H. A. Deluyker, Y. H. Schukken, and T. J. G. M. Lam. 1999. Quarter-milk somatic cell count at calving and at the first six milkings after calving. Prev. Vet. Med. 38:1-9. https://doi .org/10.1016/S0167-5877(98)00142-1.

Bewley, J. M., R. E. Boyce, J. Hockin, L. Munksgaard, S. D. Eicher, M. E. Einstein, and M. M. Schutz. 2010. Influence of milk yield, stage of lactation and body condition on dairy cattle lying behaviour measured using an automated activity monitoring sensor. J. Dairy Res. 77:1-6. https://doi.org/10.1017/S0022029909990227.

Bradley, A. J., and M. J. Green. 2004. The importance of the nonlactating period in the epidemiology of intramammary infection and strategies for prevention. Vet. Clin. North Am. Food Anim. Pract. 20:547-568. https://doi.org/10.1016/j.cvfa.2004.06.010.

Canadian Council on Animal Care. 2009. CCAC Guidelines on: The Care and Use of Farm Animals in Research, Teaching and Testing. Canadian Council on Animal Care.

Chapinal, N., G. Zobel, K. Painter, and K. E. Leslie. 2014. Changes in lying behavior after abrupt cessation of milking and regrouping at dry-off in freestall-housed cows: A case study. J. Vet. Behav. 9:364-369. https://doi.org/10.1016/j.jveb.2014.07.008.

Dahl, G. E., R. L. Wallace, R. D. Shanks, and D. Lueking. 2004. Hot topic: Effects of frequent milking in early lactation on milk yield and udder health. J. Dairy Sci. 87:882-885. https://doi.org/ 10.3168/jds.S0022-0302(04)73232-4.

Deluyker, H. A., R. H. Shumway, W. E. Wecker, A. S. Azari, and L. D. Weaver. 1990. Modeling daily milk yield in Holstein cows using time series analysis. J. Dairy Sci. 73:539-548. https://doi.org/10 .3168/jds.S0022-0302(90)78701-2.

Fogsgaard, K. K., C. M. Rontved, P. Sorensen, and M. S. Herskin. 2012. Sickness behavior in dairy cows during Escherichia coli mastitis. J. Dairy Sci. 95:630-638. https://doi.org/10.3168/jds.2011 -4350 .

Gott, P. N., P. J. Rajala-Schultz, G. M. Schueneman, K. L. Proudfoot, and J. S. Hogan. 2016. Intramammary infections and milk leakage following gradual and abrupt cessation of milking. J. Dairy Sci 99:4005-4017. https://doi.org/10.3168/jds.2015-10348.

Gott, P. N., P. J. Rajala-Schultz, G. M. Schuenemann, K. L. Proudfoot, and J. S. Hogan. 2017. Effect of gradual or abrupt cessation of milking at dry off on milk yield and somatic cell score on the subsequent lactation. J. Dairy Sci. 100:2080-2089. https://doi .org/10.3168/jds.2016-11444.

Græsbøll, K., C. Kirkeby, S. S. Nielsen, T. Halasa, N. Toft, and L. E. Christiansen. 2016. Models to estimate lactation curves of milk yield and somatic cell count in dairy cows at the herd level for the use in simulations and predictive models. Front. Vet. Sci. 3:115. https://doi.org/10.3389/fvets.2016.00115.

Hovinen, M., A. M. Aisla, and S. Pyörälä. 2005. Visual detection of technical success and effectiveness of teat cleaning in two automatic milking systems. J. Dairy Sci. 88:3354-3362. https://doi.org/10 .3168/jds.S0022-0302(05)73019-8.

Knight, C. H., and C. J. Wilde. 1993. Mammary cell changes during pregnancy and lactation. Livest. Prod. Sci. 35:3-19. https://doi .org/10.1016/0301-6226(93)90178-K.

Leslie, K. E., and C. S. Petersson-Wolfe. 2012. Assessment and management of pain in dairy cows with clinical mastitis. Vet. Clin. North Am. Food Anim. Pract. 28:289-305. https://doi.org/10 .1016/j.cvfa.2012.04.002.

Lusis, I., A. Laurs, and V. Antane. 2019. Viscosity method in robotic milking system for detection of somatic cell count in milk. Proceedings of the 18th International Scientific Conference, Engineering for Rural Development. Latvia University of Life Sciences and Technologies. https://doi.org/10.22616/ERDev2019.18.N095.

Maselyne, J., M. Pastell, P. Thomsen, V. Thorup, L. Hänninen, J. Vangeyte, A. Van Nuffel, and L. Munksgaard. 2017. Daily lying time, motion index and step frequency in dairy cows change throughout lactation. Res. Vet. Sci. 110:1-3. https://doi.org/10 .1016 /j.rvsc.2016.10.003.

Morris, T. R. 1999. Experimental Design and Analysis in Animal Sciences. CABI Publishing.

Padua, F., M. T. M. King, and T. J. DeVries. 2021. Translactational associations of dry off management, milking activity, and somatic cell count in herds with automated milking systems. Can. J. Anim. Sci. 101:400-404. https://doi.org/10.1139/cjas-2020-0066.

Prescott, N. B., T. T. Mottram, and A. J. F. Webster. 1998. Relative motivations of dairy cows to be milked or fed in a Y-maze and an automatic milking system. Appl. Anim. Behav. Sci. 57:23-33. https://doi.org/10.1016/S0168-1591(97)00112-3.

Rajala-Schultz, P. J., P. N. Gott, K. L. Proudfoot, and G. M. Schuenemann. 2018. Effect of milk cessation method at dry-off on behavioral activity of dairy cows. J. Dairy Sci. 101:3261-3270. https:// doi.org/10.3168/jds.2017-13588.

Rajala-Schultz, P. J., J. S. Hogan, and K. L. Smith. 2005. Short communication: Association between milk yield at dry-off and probability of intramammary infections at calving. J. Dairy Sci. 88:577-579. https://doi.org/10.3168/jds.S0022-0302(05)72720-X.

Shortall, J., C. Foley, C. Sleator, and C. O'Brien. 2018. The effect of concentrate supplementation on milk production and cow traffic in early and late lactation in a pasture-based automatic milking system. Animal 12:853-863. https://doi.org/10.1017/ S1751731117002221.

Siewart, J. M., J. Salfer, and M. I. Endres. 2019. Milk yield and milking station visits of primiparous versus multiparous cows on auto- 
matic milking system farms in the Upper Midwest United States. J. Dairy Sci. 102:3523-2520. https://doi.org/10.3168/jds.2018 -15382 .

Tucker, C. B., D. E. Dalley, J.-L. K. Burke, and D. A. Clark. 2007. Milking cows once daily influences behavior and udder firmness at peak and mid lactation. J. Dairy Sci. 90:1692-1703. https://doi .org/10.3168/jds.2006-577.

Tucker, C. B., S. J. Lacy-Hulbert, and J. R. Webster. 2009. Effect of milking frequency and feeding level before and after dry-off on dairy cattle behavior and udder characteristics. J. Dairy Sci. 92:3194-3203. https://doi.org/10.3168/jds.2008-1930.

Wiggans, G. R., and G. E. Shook. 1987. A lactation measure of somatic cell count. J. Dairy Sci. 70:2666-2672. https://doi.org/10 3168/jds.S0022-0302(87)80337-5.

Zobel, G., K. E. Leslie, D. M. Weary, and M. A. G. von Keyserlingk. 2013. Gradual cessation of milking reduces milk leakage and motivation to be milked in dairy cows at dry-off. J. Dairy Sci. 96:50645071. https://doi.org/10.3168/jds.2012-6501.
Zobel, G., D. M. Weary, K. E. Leslie, and M. A. G. von Keyserlingk. 2015. Invited Review: Cessation of lactation: Effects on animal welfare. J. Dairy Sci. 98:8263-8277. https://doi.org/10.3168/jds .2015-9617.

\section{ORCIDS}

A. E. France $\odot$ https://orcid.org/0000-0001-8710-1469

S. Dufour (1) https://orcid.org/0000-0001-6418-0424

D. F. Kelton (ㄴ) https://orcid.org/0000-0001-9606-7602

H. W. Barkema @ https://orcid.org/0000-0002-9678-8378

D. Kurban ๑ https://orcid.org/0000-0002-9298-9076

T. J. DeVries ๑ https://orcid.org/0000-0001-9364-2456 